\title{
Skeletons in the Cupboard of Dysfunctional Neutrophils Revealed
}

Neutrophils are key cells in host defense, playing a broad range of roles, and we would not stay alive in their absence [1-6]. Thus, impaired effector functions of these cells, as exemplified by chronic granulomatous disease, may result in significant immunodeficiencies [7]. The actin cytoskeleton plays important roles in the functions of neutrophils, and mutations can result in impaired motility, signaling, proliferative capacity, and defective antimicrobial host defense. In an excellent and comprehensive review, Evelien Sprenkeler, Steven Webbers, and Taco Kuijpers describe what is known with respect to the effect of these mutations on human neutrophil function [8].

Asthma is one of the most prevalent chronic diseases and is nowadays recognized as highly heterogeneous, requiring individualized treatment [9]. Group 2 innate lymphoid cells play key roles in both allergic and eosinophilic asthma [10]. These cells interact with CD4+ T cells that acquire a Th2 profile. In this issue, Wang et al. [11] show that downregulation of miRNA-451a upregulates the proto-oncogene ETS1 expression, contributing to Th2 cell differentiation in asthma. This mechanism could be a future therapeutic target for the treatment of asthma.

Sepsis is a condition that continues to plague individuals worldwide, and the Journal of Innate Immunity has published many articles reflecting different perspectives on this "syndrome," not least in recent years [12-15]. Yang et al. [16] present a study in this issue, showing that

karger@karger.com www.karger.com/jin

Karger"

BOPEN ACCESS
(C) 2021 The Author(s)

Published by S. Karger AG, Basel

This is an Open Access article licensed under the Creative Commons Attribution-NonCommercial-4.0 International License (CC BY-NC) (http://www.karger.com/Services/OpenAccessLicense), applicable to the online version of the article only. Usage and distribution for commercial purposes requires written permission. double-stranded RNA-dependent kinase R (PKR), an intracellular sensor of viral infection, plays a key role in host defense during polymicrobial sepsis . PKR deficiency or inhibition markedly decreased release of the key cytokine interleukin (IL)-1 $\beta$ and impaired IL-1 signaling phenocopied the effect. The findings define a critical role for the PKR-signaling pathway in antibacterial immunity.

Finally, Bleul et al. [17] investigated immunological differences in $\mathrm{C} 57 \mathrm{BL} / 6 \mathrm{~J}$ - and $\mathrm{BALB} / \mathrm{c}$-recipient mouse corneal transplantation models. They could demonstrate strain-dependent differences and C57BL/6J-recipient mice might be particularly suited to study corneal graft rejection. A mouse may thus not simply be a mouse.

This is the first issue of Journal of Innate Immunity in 2021, and as always, we hope it will provide interesting articles to the readership of the journal. We also hope that during 2021, the tide will turn with regard to the ongoing COVID-19 pandemic, where hopefully vaccines will relieve the suffering of individuals as well as the burden on society.

Heiko Herwald, Lund

Arne Egesten, Lund

\section{Conflict of Interest Statement}

The authors have no conflicts of interest to disclose. 


\section{References}

1 Nauseef WM, Borregaard N. Neutrophils at work. Nat Immunol. 2014 Jul;15(7):602-11.

2 Moraes JA, Frony AC, Barcellos-de-Souza P, Menezes da Cunha M, Brasil Barbosa Calcia T, Benjamim CF, et al. Downregulation of microparticle release and pro-inflammatory properties of activated human polymorphonuclear neutrophils by LMW fucoidan. J Innate Immun. 2019;11(4):330-46.

3 Powell RL, Fox A, Itri V, Zolla-Pazner S. Primary human neutrophils exhibit a unique HIV-directed antibody-dependent phagocytosis profile. J Innate Immun. 2019;11(2) 181-90.

4 Stockfelt M, Christenson K, Andersson A, Björkman L, Padra M, Brundin B, et al. Increased $\mathrm{CD} 11 \mathrm{~b}$ and decreased $\mathrm{CD} 62 \mathrm{~L}$ in blood and airway neutrophils from long-term smokers with and without COPD. J Innate Immun. 2020;12(6):480-9.

5 Lemaitre J, Cosma A, Desjardins D, Lambotte O, Le Grand R. Mass cytometry reveals the immaturity of circulating neutrophils during SIV infection. J Innate Immun. 2020;12(2): $170-81$.

6 Patras KA, Ha AD, Rooholfada E, Olson J, Ramachandra Rao SP, Lin AE, et al. Augmentation of urinary lactoferrin enhances host innate immune clearance of uropathogenic Escherichia coli. J Innate Immun. 2019;11(6): 481-95.
7 Roos D. Chronic granulomatous disease. Methods Mol Biol. 2019;1982:531-42.

8 Sprenkeler EG, Webbers SD, Kuijpers TW. When Actin is not actin' like it should: a new category of distinct primary immunodeficiency disorders. J Innate Immun. DOI: 10.1159/000509717. Epub 2020 Aug 26.

9 Pavord ID, Beasley R, Agusti A, Anderson GP, Bel E, Brusselle G, et al. After asthma: redefining airways diseases. Lancet. 2018 Jan; 391(10118):350-400.

10 van der Ploeg EK, Carreras Mascaro A, Huylebroeck D, Hendriks RW, Stadhouders R. Group 2 innate lymphoid cells in human respiratory disorders. J Innate Immun. 2020; 12(1):47-62.

11 Wang T, Zhou Q, Shang Y. Downregulation of miRNA-451a promotes the differentiation of CD4+ T cells towards Th2 cells by upregulating ETS1 in childhood asthma. J Innate Immun. DOI: 10.1159/000509714. Epub 2020 Dec 3.

12 Linder A, Fjell CD, Inghammar M, Hsu J, Walley KR, Boyd JH, et al. The specific organism: not bacterial Gram type: drives the inflammatory response in septic shock. J Innate Immun. 2020;12(2):182-90.
13 Issara-Amphorn J, Chancharoenthana W, Visitchanakun P, Leelahavanichkul A. Syk inhibitor attenuates polymicrobial sepsis in FcgRIIb-deficient lupus mouse model, the impact of lupus characteristics in sepsis. J Innate Immun. 2020;12(6):461-79.

14 Claushuis TA, de Vos AF, Roelofs JJ, de Boer OJ, van 't Veer C, van der Poll T. Plateletdense granules worsen pre-infection thrombocytopenia during Gram-negative pneumonia-derived sepsis. J Innate Immun. 2019; 11(2):168-80.

15 Olinder J, Ehinger D, Liljenborg E, Herwald $\mathrm{H}$, Rydén C. Plasma levels of hepcidin and reticulocyte haemoglobin during septic shock. J Innate Immun. 2020;12(6):448-60.

16 Yang Y, Xie L, Zhong Y, Zhong X, Meng R, Xue Q, et al. Double-stranded RNA dependent kinase $\mathrm{R}$ regulates antibacterial immunity in sepsis. J Innate Immun. DOI: 10.1159/000507932. Epub 2020 Dec 17.

17 Bleul T, Zhuang X, Hildebrand A, Lange C, Böhringer D, Schlunck G, et al. Different innate immune responses in $\mathrm{BALB} / \mathrm{c}$ and C57BL/6 strains following corneal transplantation. J Innate Immun. DOI: 10.1159/ 000509716. Epub 2020 Sep 9. 